Check for updates

Cite this: Chem. Sci., 2018, 9, 8567

๑ All publication charges for this article have been paid for by the Royal Society of Chemistry

Received 26th July 2018

Accepted 17th September 2018

DOI: $10.1039 / c 8 s c 03321 h$

rsc.li/chemical-science

\section{Simultaneous nitrosylation and N-nitrosation of a Ni-thiolate model complex of $\mathrm{Ni}$-containing SOD†}

\author{
Phan T. Truong, (D) ${ }^{a}$ Ellen P. Broering, (DD ${ }^{a}$ Stephen P. Dzul, ${ }^{b}$ Indranil Chakraborty, ${ }^{c}$ \\ Timothy L. Stemmler ${ }^{b}$ and Todd C. Harrop (ID*a
}

Nitric oxide (NO) is used as a substrate analogue/spectroscopic probe of metal sites that bind and activate oxygen and its derivatives. To assess the interaction of superoxide with the $\mathrm{Ni}$ center in $\mathrm{Ni}$-containing superoxide dismutase (NiSOD), we studied the reaction of $\mathrm{NO}^{+}$and $\mathrm{NO}$ with the model complex, $\mathrm{Et}_{4} \mathrm{~N}$

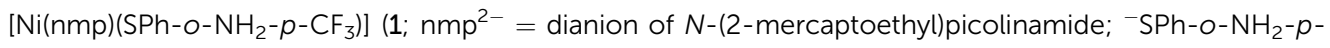
$\mathrm{CF}_{3}=2$-amino-4-(trifluoromethyl)benzenethiolate) and its oxidized analogue $1^{\text {ox }}$, respectively. The ultimate products of these reactions are the disulfide of ${ }^{-} \mathrm{SPh}-\mathrm{O}-\mathrm{NH}_{2}-\mathrm{p}-\mathrm{CF}_{3}$ and the $\mathrm{S}, \mathrm{S}$-bridged tetrameric complex $\left[\mathrm{Ni}_{4}(\mathrm{nmp})_{4}\right]$, a result of S-based redox activity. However, introduction of NO to 1 affords the green dimeric $\{\mathrm{NiNO}\}^{10}$ complex $\left(\mathrm{Et}_{4} \mathrm{~N}\right)_{2}\left[\left\{\mathrm{Ni}\left(\kappa^{2}-\mathrm{SPh}-\mathrm{O}-\mathrm{NNO}-\mathrm{p}-\mathrm{CF}_{3}\right)(\mathrm{NO})\right\}_{2}\right]$ (2) via $\mathrm{NO}-$ induced loss of $\mathrm{nmp}^{2-}$ as the disulfide and $\mathrm{N}$-nitrosation of the aromatic thiolate. Complex 2 was characterized by $\mathrm{X}$-ray crystallography and several spectroscopies. These measurements are in-line with other tetrahedral complexes in the $\{\mathrm{NiNO}\}^{10}$ classification. In contrast to the established stability of this metal-nitrosyl class, the $\mathrm{Ni}-\mathrm{NO}$ bond of 2 is labile and release of $\mathrm{NO}$ from this unit was quantified by trapping the NO with a Co"-porphyrin (70-80\% yield). In the process, the Ni ends up coordinated by two o-nitrosaminobenzenethiolato ligands to result in the structurally characterized trans$\left(\mathrm{Et}_{4} \mathrm{~N}\right)_{2}\left[\mathrm{Ni}\left(\mathrm{SPh}-\mathrm{O}-\mathrm{NNO}-\mathrm{p}-\mathrm{CF}_{3}\right)_{2}\right]$ (3), likely by a disproportionation mechanism. The isolation and characterization of 2 and 3 suggest that: (i) the strongly donating thiolates dominate the electronic structure of $\mathrm{Ni}$-nitrosyls that result in less covalent $\mathrm{Ni}-\mathrm{NO}$ bonds, and (ii) superoxide undergoes disproportionation via an outer-sphere mechanism in NiSOD as complexes in the $\{\mathrm{NiNO}\}^{9 / 8}$ state have yet to be isolated.

\section{Introduction}

Nitric oxide (NO) and its derivatives (termed reactive nitrogen species or RNS) play a vital role in a variety of mammalian (and in some cases bacterial) physiological and pathological processes..$^{1-4}$ Additionally, this gaseous free radical has applications in fundamental research, especially in bioinorganic chemistry, where it is utilized as a structural/spectroscopic probe of $\mathrm{O}_{2}$ (and other reactive oxygen species, e.g., $\mathrm{O}_{2}{ }^{--}$and $\mathrm{H}_{2} \mathrm{O}_{2}$ ) binding/activating metalloenzymes. ${ }^{5-9}$ In general, this approach is employed because metal-nitrosyl (MNO) bonds are

\footnotetext{
${ }^{a}$ Department of Chemistry, Center for Metalloenzyme Studies, The University of Georgia, Athens, Georgia, 30602,USA. E-mail: tharrop@uga.edu

${ }^{b}$ Departments of Pharmaceutical Sciences, Biochemistry, and Molecular Biology, Wayne State University, Detroit, Michigan, 48201, USA

${ }^{c}$ Department of Chemistry and Biochemistry, Florida International University, Miami, Florida, 33199, USA

$\dagger$ Electronic supplementary information (ESI) available: Synthetic and spectroscopic/reactivity details, and full crystallographic information for $\mathbf{2}$ and 3. CCDC 1850485 and 1850488. For ESI and crystallographic data in CIF or other electronic format see DOI: $10.1039 / \mathrm{c} 8 \mathrm{sc} 03321 \mathrm{~h}$
}

highly covalent, and hence more stable, than metal-dioxygen $\left(\mathrm{M}-\mathrm{O}_{2}\right)$ adducts. ${ }^{10}$ The use of $\mathrm{NO}$ as an $\mathrm{O}_{2}$ analogue is based on similar electronic structures between these diatoms and their reduced derivatives. ${ }^{3}$ For example, ${ }^{3} \mathrm{NO}^{-}$(termed the nitroxyl anion), the one electron reduced analogue of NO, is isoelectronic with $\mathrm{O}_{2}$ with two unpaired $\pi^{*}$ electrons in the HOMO. Additionally, NO, while not isoelectronic with $\mathrm{O}_{2}{ }^{-}$, has the same ground state electronic structure with a singly occupied $\pi^{*}$ MO. Thus, NO interactions with the active sites of $\mathrm{O}_{2}$ activating/ROS-breakdown enzymes report coordination (innersphere substrate binding) and the extent of substrate bond activation from vibrational spectroscopic measurements of the $\mathrm{N}-\mathrm{O}$ and $\mathrm{M}-\mathrm{NO}$ stretching frequencies.

Since 2009, our lab has designed and constructed numerous low molecular weight models of the active site of Ni-containing superoxide dismutase (NiSOD). ${ }^{\mathbf{1 1 - 1 8}}$ NiSOD is an unprecedented SOD due to $\mathrm{Ni}^{\mathrm{II} / \mathrm{II}}$-coordination to cysteinato-S (CysS) and peptido-N donors (Chart 1), the former of which is susceptible to oxidative modification by the substrate $\left(\mathrm{O}_{2}{ }^{-}\right)$and products $\left(\mathrm{O}_{2}\right.$ and $\left.\mathrm{H}_{2} \mathrm{O}_{2}\right)$ of the SOD catalyzed reaction. ${ }^{19,20}$ Few models employ ligands with the correct spatial disposition and 

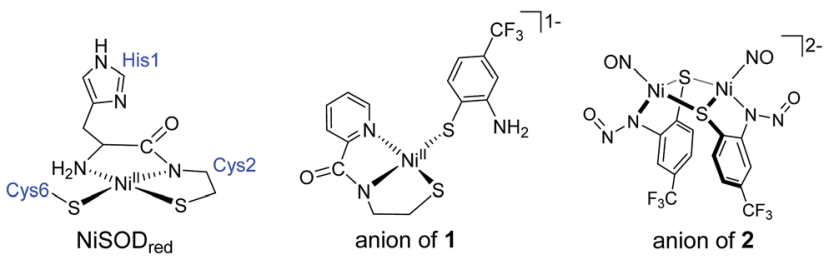

Chart 1 Structures of the active site of NiSOD red (left; His1 coordinates to $\mathrm{Ni}^{i l l}$ in $\mathrm{NiSOD}_{\mathrm{Ox}}$ ), the anion of the NiSOD model complex $\mathrm{Et}_{4} \mathrm{~N}$ [Ni(nmp)(SPh-O-NH$\left.\left.H_{2}-p-\mathrm{CF}_{3}\right)\right]$ (1) (center; $\mathrm{nmp}^{2-}=$ dianion of the $\mathrm{N}_{2} \mathrm{~S}$ ligand $\mathrm{N}$-(2-mercaptoethyl)picolinamide), and the anion of the $\left\{\mathrm{NiNO}^{10}\right.$ complex $\left(\mathrm{Et}_{4} \mathrm{~N}\right)_{2}\left[\left\{\mathrm{Ni}\left(\kappa^{2}-\mathrm{SPh}-\mathrm{O}-\mathrm{NNO}-\mathrm{p}-\mathrm{CF}_{3}\right)(\mathrm{NO})\right\}_{2}\right](2)$.

electronic nature of the unique $\mathrm{N}_{3} \mathrm{~S}_{2}$ donor set found in the active site. ${ }^{21-23}$ Moreover, fewer report reversible electrochemical and/or spectroscopic evidence for the $\mathrm{Ni}^{\mathrm{III}}$ oxidation state due to redox associated with the coordinated thiolates. One model from our lab, namely $\mathrm{Et}_{4} \mathrm{~N}\left[\mathrm{Ni}(\mathrm{nmp})\left(\mathrm{SPh}-o-\mathrm{NH}_{2}-p-\right.\right.$ $\left.\left.\mathrm{CF}_{3}\right)\right]\left(1 ; \mathrm{nmp}^{2-}=\right.$ dianion of the $\mathrm{N}_{2} \mathrm{~S}$ ligand $N$-(2-mercaptoethyl $)$ picolinamide; see Chart 1) displays a reversible redox-event at $-0.43 \mathrm{~V}\left(v s . \mathrm{Fc} / \mathrm{Fc}^{+}\right.$in DMF) that, based on EPR, UV-vis, MCD, and DFT computations, represents the electrochemical conversion from $\mathrm{Ni}^{\mathrm{II}}$ in $\mathbf{1}$ to a $\mathrm{Ni}^{\mathrm{II}}$-thiyl $\leftrightarrow \mathrm{Ni}^{\mathrm{III}}$-thiolate resonance species termed $\mathbf{1}^{\mathbf{o x}} .{ }^{16}$ Because substrate binding to Ni in NiSOD has not been defined, although most reports favor an outer-sphere mechanism, ${ }^{15,24}$ we were curious to use NO as an $\mathrm{O}_{2}{ }^{\cdot-}$ probe to define potential intermediates that may be traversed in the NiSOD mechanism. We report here, for the first time, the reactions and product characterization of NO (and $\left.\mathrm{NO}^{+}\right)$with $\mathbf{1}$ and the well-defined analogue of $\mathrm{NiSOD}_{\text {ox }}\left(\mathbf{1}^{\mathbf{o x}}\right) . \mathrm{NO} /$ $\mathrm{NO}^{+}$oxidize the aromatic thiolate ligand in $\mathbf{1}^{\mathbf{o x}}$ and $\mathbf{1}$, respectively. However, introduction of NO to $\mathbf{1}$ affords the green dimeric $\quad\{\mathrm{NiNO}\}^{10}$ complex $\left(\mathrm{Et}_{4} \mathrm{~N}\right)_{2}\left[\left\{\mathrm{Ni}\left(\kappa^{2}-S \mathrm{Ph}-o-N \mathrm{NO}-p\right.\right.\right.$ $\left.\left.\mathrm{CF}_{3}\right)(\mathrm{NO})\right\}_{2}$ ] (2) via NO-induced loss of $\mathrm{nmp}^{2-}$ as the disulfide and N-nitrosation of the aromatic thiolate (Chart 1). While 2 bears little resemblance to NiSOD, its formation indicates how reactive NiSOD models such as $\mathbf{1}$ are in the presence of redoxactive diatoms and suggest similar paths for other biological $\mathrm{Ni}$-thiolate sites. Additionally, 2 contains a labile $\mathrm{Ni}-\mathrm{NO}$ bond, a new feature for the $\{\mathrm{NiNO}\}^{10}$ formulation that appears to be controlled by the presence of the thiolate ligands. We describe the synthesis, spectroscopy, electronic structure, reactivity and mechanistic insight into the formation of the Ni-nitrosyl in this account.

\section{Results and discussion}

In the anticipation of isolating a Ni-nitrosyl as an analogue of a potential Ni-superoxo/peroxo catalytic intermediate of NiSOD, we examined the reaction of $\mathbf{1}$ with $\mathrm{NOBF}_{4}$ and in situ prepared $\mathbf{1}^{\mathbf{o x}}$ with NO (Scheme 1). In theory, both reactions yield the same product. For example, nitrosonium $\left(\mathrm{NO}^{+}\right.$; a strong oxidant, $E=$ $+0.56 \mathrm{~V} v s$. $\mathrm{Fc} / \mathrm{Fc}^{+}$in $\mathrm{DMF}^{25}$ ) will oxidize 1 to $\mathbf{1}^{\mathrm{ox}}$ and form $\mathrm{NO}$ in the process. The newly generated $\mathbf{1}^{\mathbf{o x}}(S=1 / 2)$ then reacts with $\mathrm{NO}$ to form the Ni-nitrosyl, formally a $\{\mathrm{NiNO}\}^{8}$ complex, assuming binding of $\mathrm{NO}$ and no other coordination sphere

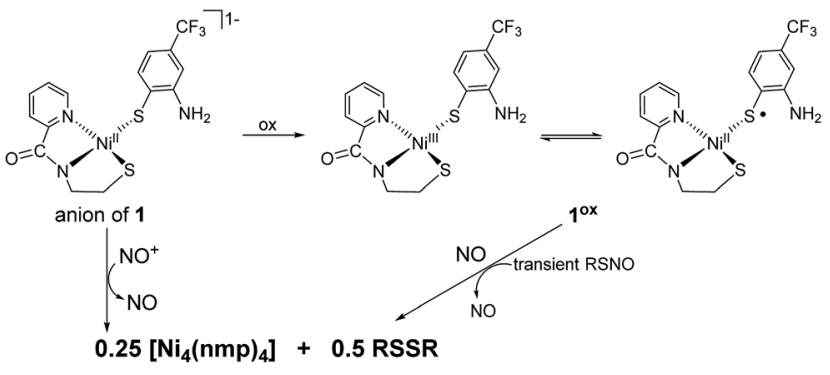

Scheme $1 \mathrm{NO}$ and $\mathrm{NO}^{+}$reactions of 1 and $1^{\text {ox }}$, respectively. $\mathrm{R}=2-$ amino-4-(trifluoromethyl)benzenethiolate.

changes, using the notation defined by Enemark and Feltham. ${ }^{26}$ Likewise, NO will readily intercept paramagnetic $\mathbf{1}^{\mathbf{o x}}$ to generate the same species. Mixing a DMF solution of 1 with $\operatorname{NOBF}_{4}(1: 1)$ resulted in instantaneous bleaching of the solution, consistent with oxidation of the $\mathrm{RS}^{-}$ligand to disulfide (RSSR), and the appearance of a dark-red precipitate that was spectroscopically identified to be the neutral $S, S$-bridged tetramer $\left[\mathrm{Ni}_{4}(\mathrm{nmp})_{4}\right]$ (Scheme 1). ${ }^{16}$ This outcome is typical for all $[\mathrm{Ni}(\mathrm{nmp})(\mathrm{SR})]^{-}$ complexes when treated with chemical oxidants, i.e., Soxidation of the coordinated monodentate thiolate to RSSR. ${ }^{15}$ Incidentally, the same result was obtained when introducing $\mathrm{NO}(\mathrm{g})$ into a DMF solution of in situ generated $\mathbf{1}^{\mathbf{0 x}}$. In this case, formation of the disulfide may traverse a fleeting, and yet to be characterized, RSNO intermediate that releases NO via homolytic cleavage of the RS-NO bond (Scheme 1). ${ }^{27}$ Overall, a Ninitrosyl was not isolated. This result may not be too surprising considering that all known Ni-nitrosyls are in the $\{\mathrm{NiNO}\}^{10}$ Enemark-Feltham (EF) classification, ${ }^{28}$ although a $\left\{\mathrm{NiNO}^{9 / 8}\right.$ species is not entirely unrealistic in light of the strong donors present in $\mathbf{1}$ and in NiSOD, i.e., peptido-N and alkyl-thiolato-S.

As a control, we also explored the reaction of $\mathrm{Ni}^{\mathrm{II}}$ complex $\mathbf{1}$ with NO. In general, NO does not react with square-planar $[\mathrm{Ni}(\mathrm{nmp})(\mathrm{SR})]^{-}(\mathrm{R}=$ simple aryl or alkyl groups) complexes due to their diamagnetic nature. However, when $\mathrm{R}$ contains a potentially bidentate chelate, as in $\mathbf{1}$, a different course takes place. For instance, exposing a DMF solution of 1 with $\mathrm{NO}(\mathrm{g})$ for $30 \mathrm{~s}$ resulted in a gradual change of the solution from dark-red to green over several minutes. Workup of this reaction indicated a Ni-nitrosyl based on the strong double-humped peak in the $\mathrm{N}-\mathrm{O}$ stretching $\left(\nu_{\mathrm{NO}}\right)$ region of the IR spectrum (vide infra). Subsequent crystallization of the bulk material from MeCN/ $\mathrm{Et}_{2} \mathrm{O}$ at $-20^{\circ} \mathrm{C}$ resulted in green crystals of a dinuclear thiolatebridged $\quad\{\mathrm{NiNO}\}^{10}$ complex $\left(\mathrm{Et}_{4} \mathrm{~N}\right)_{2}\left[\left\{\mathrm{Ni}\left(\kappa^{2}-\mathrm{SPh}-o-N \mathrm{NO}-p\right.\right.\right.$ $\left.\left.\left.\mathrm{CF}_{3}\right)(\mathrm{NO})\right\}_{2}\right]$ (2) as depicted in Fig. 1 with selected metric parameters listed in Table 1. The Ni centers in 2 are distorted tetrahedral $\left(\tau_{4}=0.73\right.$ (ref. 29)) resulting from $\mathrm{N}_{2} \mathrm{~S}_{2}$ coordination of the thiolato-S/deprotonated amine- $\mathrm{N}$ of the S-bridged $o$ nitrosaminobenzenethiolate and a terminal nitrosyl. To our knowledge, complex 2 represents the first example of a structurally characterized first-row metal complex with both a coordinated nitrosyl and amine-N-bound nitrosamine. In accord with other tetrahedral $\left\{\mathrm{NiNO}^{10}{ }^{\text {complexes }^{28}}\right.$ the $\mathrm{Ni}-\mathrm{N}(\mathrm{O})$ 


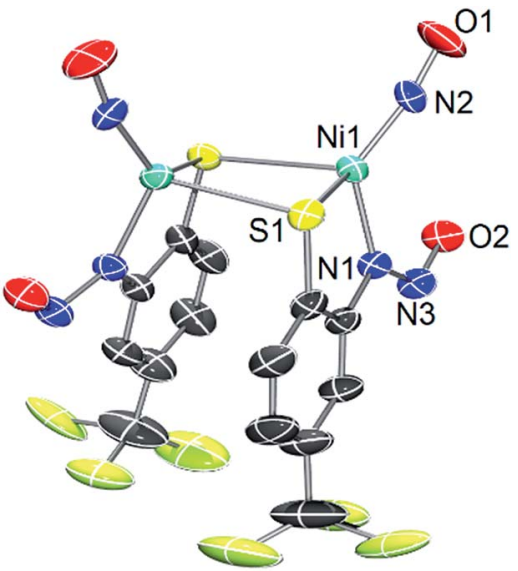

Fig. 1 X-ray structure of the anionic portion of 2 with the atom labeling scheme (50\% thermal probability). $\mathrm{H}$ atoms and $\mathrm{Et}_{4} \mathrm{~N}^{+}$counterions are omitted for clarity.

Table 1 Selected bond distances $(\AA)$ and bond angles (deg) from the $X$-ray crystal structure of 2, compared with the DFT-optimized model 2*

\begin{tabular}{lll}
\hline & & $\begin{array}{l}\text { DFT (BP86/def2-TZVPP) } \\
\text { optimized structure 2* }\end{array}$ \\
\hline Ni1-S1 & $2.3169(7)$ & 2.294 \\
Ni1-S1' & $2.3555(6)$ & 2.344 \\
Ni1-N2 & $1.659(7)$ & 1.648 \\
Ni1-N1 & $1.971(2)$ & 1.974 \\
N2-O1 & $1.182(8)$ & 1.191 \\
N1-N3 & $1.299(3)$ & 1.324 \\
N3-O2 & $1.269(3)$ & 1.254 \\
S1-Ni-S1 & $96.66(2)$ & 90.05 \\
S1-Ni-N1 & $86.21(6)$ & 86.67 \\
S1'-Ni-N1 & $99.10(6)$ & 98.40 \\
S1-Ni-N1 & $123.8(5)$ & 125.92 \\
N2-Ni-S1 & $109.8(6)$ & 113.43 \\
N1-Ni-N2 & $133.6(5)$ & 132.15 \\
Ni1-N2-O1 & $167.8(12)$ & 171.42 \\
N1-N3-O3 & $114.2(2)$ & 115.80 \\
$\tau_{4}$ & 0.73 & 0.72
\end{tabular}

distance is short (1.659 $\AA)$, the N-O bond (1.182 $\AA$ ) is intermediate between free $\mathrm{NO}^{\circ}(1.15 \AA)$ and ${ }^{1} \mathrm{HNO}(1.21 \AA),{ }^{10}$ and the $\mathrm{Ni}-$ $\mathrm{N}-\mathrm{O}$ bond angle is close to linear albeit slightly bent $\left(167.8^{\circ}\right)$ (see Table 1). Complex 2 is analogous to the limited number of four-coordinate/S-bound Ni-nitrosyls, ${ }^{30-34}$ fewer of which contain Ni-S $\mathrm{S}_{\text {thiolate }}$ bonds $^{31,33}$ which display $\mathrm{Ni}-\mathrm{N}(\mathrm{O})(1.663-$ $1.683 \AA), \mathrm{N}-\mathrm{O}\left(1.131-1.173 \AA\right.$ ), and $\mathrm{Ni}-\mathrm{N}-\mathrm{O}\left(156.6-173.9^{\circ}\right)$ distances/angles in similar ranges. Even neutral/cationic $\mathrm{P}^{35-40}$ and N-bound ${ }^{34,41-43} \quad \mathrm{~L}_{3} \mathrm{Ni}-\mathrm{NO} / \mathrm{L}_{2} \mathrm{XNi}-\mathrm{NO}$ complexes exhibit similar metric parameters. The coordinated nitrosamine is bent $\left(\mathrm{N}-\mathrm{N}-\mathrm{O}: 115.4^{\circ}\right)$, i.e., $\mathrm{sp}^{2}$-hybridized nitroso- $\mathrm{N}$, with $\mathrm{N}-\mathrm{N}$ and $\mathrm{N}-\mathrm{O}$ distances of 1.299 and $1.269 \AA$, respectively. These values suggest a small degree of delocalization in the $\mathrm{R}-\mathrm{N}-\mathrm{N}-\mathrm{O}$ unit. However, the structure is more biased towards the nitrosamino $\mathrm{R}-\mathrm{N}^{-}-\mathrm{N}=\mathrm{O}$ versus diazoate $\mathrm{R}-\mathrm{N}=\mathrm{N}-\mathrm{O}^{-}$resonance form. To compare, the structure of syn-methanediazoate $(\mathrm{N}-\mathrm{N}: 1.246 \AA$,
$\mathrm{N}-\mathrm{O}: 1.306 \AA$ ) reflects the true double bond character in an authentic $\mathrm{R}-\mathrm{N}=\mathrm{N}-\mathrm{O}$ unit. ${ }^{44}$ These values are somewhat comparable to other $\mathrm{N}$-bound nitrosamine complexes, ${ }^{45,46}$ especially $\left[\mathrm{CpNi}\left(\mathrm{PPh}_{3}\right)\left(\mathrm{ON}_{2} \mathrm{Ph}-p-\mathrm{NO}_{2}\right)\right](\mathbf{I})^{47}(\mathrm{~N}-\mathrm{N}: 1.327 \AA$ А $\mathrm{N}-\mathrm{O}$ : $\left.1.249 \AA, \mathrm{N}-\mathrm{N}-\mathrm{O}: 113.1^{\circ}\right)$. Structures of coordinated nitroso-Nmetal complexes (vs. amine- $\mathrm{N}$ as in 2) also afford similar structural parameters in the RNNO. ${ }^{48}$ In contrast, O-bound nitrosamine complexes appear to favor more of a resonance delocalized structure as the $\mathrm{N}-\mathrm{N}(1.275-1.288 \AA)$ and $\mathrm{N}-\mathrm{O}$ (1.251-1.275 ̊) distances in a series of $\left[\mathrm{Fe}^{\mathrm{III}}(\mathrm{P})\left(\mathrm{ONNR}_{2}\right)_{2}\right]^{+}(\mathrm{P}=$ porphyrin) complexes are nearly identical and result in a single ${ }^{15} \mathrm{~N}$-sensitive peak in the IR due to overlapping $\nu_{\mathrm{NN}} / \nu_{\mathrm{NO}}$ modes. $^{49-51}$

Complex 2 was characterized by a variety of spectroscopic methods. The solid-state IR spectrum (KBr matrix) of 2 exhibits two closely spaced, but well-resolved, $\nu_{\mathrm{NO}}$ at 1759 and $1743 \mathrm{~cm}^{-1}$ (1724, $1708 \mathrm{~cm}^{-1}$ for $2{ }^{-15} \mathrm{NO} ; \Delta \nu_{\mathrm{NO}}: 35 \mathrm{~cm}^{-1}$; see Fig. 2). These values fall in the range of known tetrahedral, neutral, and anionic $\{\mathrm{NiNO}\}^{10}$ complexes. ${ }^{28}$ Because 2 is of $C_{2}$ symmetry (cis $\mathrm{NO}$, syn bridging thiolates), two IR-active $\mathrm{N}-\mathrm{O}$ vibrational modes are expected. The other feasible isomer of 2 would be of $C_{i}$ symmetry (trans $\mathrm{NO}$, anti bridging thiolates) and would display one IR-active $\mathrm{N}-\mathrm{O}$ stretch. Indeed, the IR spectrum of 2 in DMSO exhibits one $\nu_{\mathrm{NO}}$ at $1784 \mathrm{~cm}^{-1}$ suggesting possible $c i s /$ trans-NO conversion in solution (or an averaged $\nu_{\mathrm{NO}}$ value due to rapid tumbling) or thiolate-bridge splitting to yield a four-
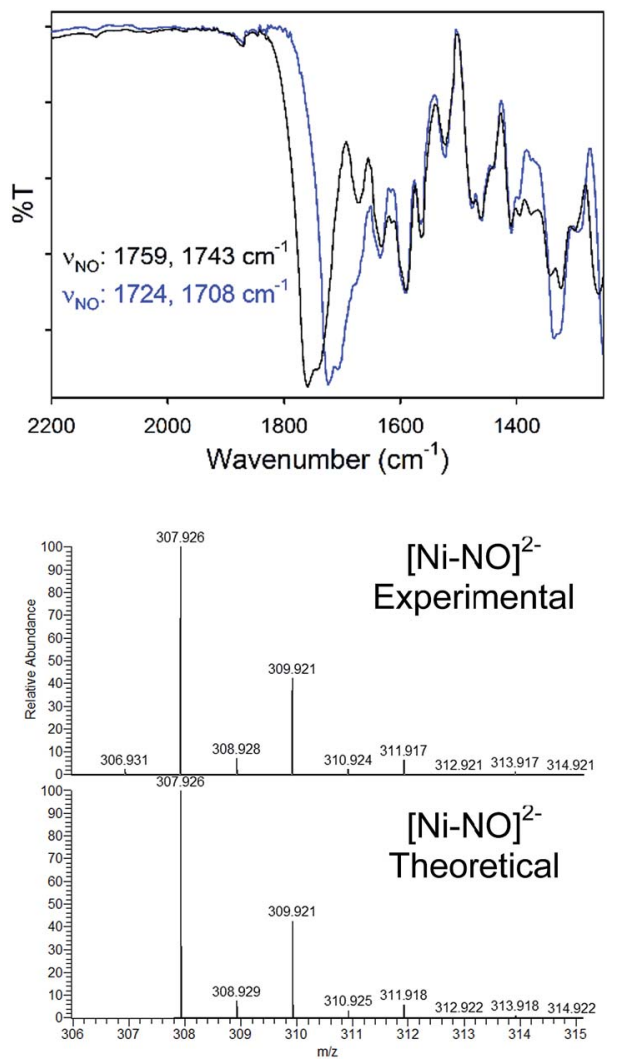

Fig. 2 (Top) Solid-state IR of the $\nu_{\mathrm{NO}}$ region for 2 (black) and $2-{ }^{15} \mathrm{NO}$ (blue) in a $\mathrm{KBr}$ matrix. (Bottom) High resolution ESI-MS(-) of 2 with the theoretical isotopic distribution. 
coordinate mononuclear $\{\mathrm{NiNO}\}^{10}$ with DMSO as the fourth ligand, i.e., $\left[\mathrm{Ni}\left(\kappa^{2}-\mathrm{SPh}-o-\mathrm{NNO}-p-\mathrm{CF}_{3}\right)(\mathrm{DMSO})(\mathrm{NO})\right]^{-}$. The ${ }^{1} \mathrm{H}$ NMR spectrum of 2 in $\mathrm{CD}_{3} \mathrm{CN}$ (Fig. S6 $\dagger$ ) or DMSO-d $\mathrm{d}_{6}$ (not shown) are similar and thus do not distinguish any of the proposed structures. Comparable IR spectral changes in the opposite direction are observed for the one other thiolatesupported anionic dinuclear $\{\mathrm{NiNO}\}^{10},\left(\mathrm{Et}_{4} \mathrm{~N}\right)_{2}\left[\mathrm{Ni}_{2}(\mathrm{NO})_{2}(\mu-\right.$ $\left.\mathrm{SPh})_{2}(\mathrm{SPh})_{2}\right]$ (II), with trans NO ligands $\left(\nu_{\mathrm{NO}}: 1709 \mathrm{~cm}^{-1}\right.$ in $\mathrm{KBr}$; $1751,1721 \mathrm{~cm}^{-1}$ in THF). ${ }^{33} \mathrm{~A}$ similar situation is described for a pyrazolate-bridged anionic dinuclear $\{\mathrm{NiNO}\}^{10}$ complex. ${ }^{52} \mathrm{IR}$ peaks arising from the nitrosamine were not as obvious due to multiple overlapping peaks in the region (Fig. S5 $\dagger$ ). However, ${ }^{15} \mathrm{~N}$-sensitive peaks in the IR of 2 at 1342 and $1258 \mathrm{~cm}^{-1}(1326$, $1249 \mathrm{~cm}^{-1}$ in $2{ }^{15} \mathrm{NO}$ ) are assigned as $\nu_{\mathrm{NO}}$ and $\nu_{\mathrm{NN}}$, respectively. In comparison, a series of secondary nitrosamines display $\nu_{\mathrm{NO}}$ : $1428-1463 \mathrm{~cm}^{-1}$ and $\nu_{\mathrm{NN}}: 1035-1154 \mathrm{~cm}^{-1}$ in $\mathrm{CCl}_{4}{ }^{.53}$ Therefore, a significant degree of delocalization occurs in the RNNO unit of 2 to cause the corresponding downshift in $\nu_{\mathrm{NO}} /$ upshift in $\nu_{\mathrm{NN}}$. While no paramagnetically shifted resonances are observed in the ${ }^{1} \mathrm{H}$ NMR $\left(\mathrm{CD}_{3} \mathrm{CN}\right)$ of 2 , several species are indicated in freshly prepared solutions (Fig. S6 $\dagger$ ) that are likely caused by the lability of the $\mathrm{Ni}-\mathrm{NO}$ bond and presence of $\mathrm{nmpS}_{2}$ (vide infra). The ${ }^{15} \mathrm{~N}$ NMR spectrum of $2^{-{ }^{15}} \mathrm{NO}$ confirms multiple solution speciation with four major peaks in the range for nitrosamines and linearly coordinated NO $\left(\delta: 40-190 \mathrm{ppm}\right.$ in $\mathrm{CD}_{3} \mathrm{CN}$, vs. $\mathrm{CH}_{3} \mathrm{NO}_{2}$, Fig. S7 $\dagger$ ). ${ }^{54-57}$ Moreover, the ${ }^{1} \mathrm{H}$ NMR of thiolatebridged dinuclear complex II displays broadened aryl-H resonances caused by rapid exchange of $\mathrm{PhS}^{-}$ligands because of disproportionation to the mononuclear $\left(\mathrm{Et}_{4} \mathrm{~N}\right)_{2}\left[\mathrm{Ni}(\mathrm{NO})(\mathrm{SPh})_{3}\right]$ (III) and an uncharacterized [Ni(NO)(SPh)] species. ${ }^{33}$ However, high-resolution electrospray ionization mass spectrometry (HRESI-MS; negative mode) displays one dominant compound with the formula and isotopic distribution consistent with the dianionic portion of $2(m / z: 307.926, z=2$, Fig. 2, S8 and S9†) and $2{ }^{15} \mathrm{NO}(\mathrm{m} / z: 309.920, z=2$; Fig. S10 and S11 $\dagger$ ), although this measurement does not discriminate against cis and trans NO conformers. Another minor peak in the HR-ESI-MS(-) is centered at $m / z: 248.960(z=2$; Fig. S8 $\dagger)$ that suggests a new $\left[\mathrm{Ni}\left(\mathrm{N}_{2} \mathrm{~S}_{2}\right)\right]^{2-}$ species through loss of the Ni-coordinated NO and one Ni (vide infra).

Solutions of 2, especially in donor solvents such as MeCN or DMF, gradually lose their green color to give red-brown solutions more reminiscent of square-planar $\mathrm{Ni}^{\mathrm{II}}-\mathrm{N}_{2} \mathrm{~S}_{2}$ complexes. ${ }^{15,58}$ Even freshly prepared $\mathrm{CD}_{3} \mathrm{CN}$ solutions of 2 exhibit multiple peaks in the ${ }^{1} \mathrm{H} /{ }^{15} \mathrm{~N}$ NMR, and ESI-MS shows a new species with a $\mathrm{Ni}$ isotope pattern at $m / z \sim 249$ (vide supra). This change is enhanced when vacuum is applied and FTIR spectra of these reaction mixtures lack any $\nu_{\mathrm{NO}}$ suggesting the loss of coordinated $\mathrm{NO}$ from 2 to generate a new Ni species. Slow diffusion of $\mathrm{Et}_{2} \mathrm{O}$ into MeCN solutions of 2 that have been left standing for several weeks result in crystals $(10-20 \%$ isolated yield from crystallization) of a square-planar $\left(\tau_{4}=0.12\right)$ $\mathrm{Ni}^{\mathrm{II}}$ compound where two $\mathrm{N}, \mathrm{S}$-chelating $o$-nitrosaminobenzenethiolato ligands bind to $\mathrm{Ni}$ in a trans configuration, viz. trans- $\left(\mathrm{Et}_{4} \mathrm{~N}\right)_{2}\left[\mathrm{Ni}\left(\mathrm{SPh}-o-\mathrm{NNO}-p-\mathrm{CF}_{3}\right)_{2}\right]$ (3) (Fig. 3). The bond lengths (Ni-S: $2.2072 \AA$, Ni-N: $1.896 \AA$ ) and angles (Table $\mathrm{S} 3 \dagger)$ are similar to other planar $\mathrm{Ni}^{\mathrm{II}}-\mathrm{N}_{2} \mathrm{~S}_{2}$ complexes that

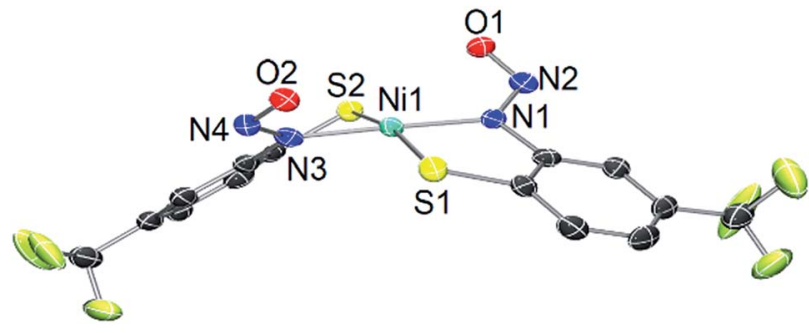

Fig. 3 X-ray structure of the dianion of 3 with the atom-labeling scheme $(50 \%$ thermal probability). One of two crystallographically distinct molecules shown. $\mathrm{H}$ atoms, $\mathrm{Et}_{4} \mathrm{~N}^{+}$counterions, and solvent of crystallization $\left(\mathrm{Et}_{2} \mathrm{O}\right)$ are omitted for clarity.

contain $\kappa^{2}$-N,S-o-aminobenzenethiolate ligands..$^{59-61}$ The Ni-N distance in $\mathbf{3}$ is shorter than the typical $\mathrm{Ni}-\mathrm{N}_{\text {amine }}$ bond and reflects the enhanced donor strength of the deprotonated nitrosamino-N, which is comparable to, although weaker than, a $\mathrm{Ni}-\mathrm{N}_{\text {carboxamido }}(\sim 1.86 \AA) .{ }^{15,58}$ No evidence for a coordinated ligand radical is evident from the $\mathrm{X}$-ray structure (i.e., short $\mathrm{C}-\mathrm{S}$, $\mathrm{C}-\mathrm{N}$ distances of the coordinated $o$-aminobenzenethiolate ${ }^{62}$ ) and confirm the N,S-ligand is a closed-shell dianion. The $\mathrm{R}-\mathrm{N}-$ $\mathrm{N}-\mathrm{O}$ linkage in 3 (avg. of two crystallographically distinct molecules, $\mathrm{N}-\mathrm{N}: 1.309 \AA$, N-O: $1.264 \AA$; avg. $\mathrm{N}-\mathrm{N}-\mathrm{O}: 115.2^{\circ}$ ) is unremarkable from $2 .{ }^{1} \mathrm{H}$ and ${ }^{15} \mathrm{~N}$ NMR $\left(\mathrm{RN}^{15} \mathrm{NO}, \delta: 194 \mathrm{ppm} v s\right.$. $\mathrm{CH}_{3} \mathrm{NO}_{2}$ ) of crystals of 3 are consistent with the X-ray structure and analogous to other nitrosamines (Fig. S13 and S14†). ${ }^{55,57}$ As expected, the IR of 3 lacks the intense $\nu_{\mathrm{NO}}$ from the NiNO of 2 (although IR and ESI-MS show that some 2 remains even in crystals of 3, Fig. S12 $\dagger$ ) and the $\nu_{\mathrm{NO}}$ and $\nu_{\mathrm{NN}}$ of the R-N-N-O unit is similar. HR-ESI-MS(-) confirm this formulation with peaks corresponding to $\left[\mathrm{M}^{-2}-\mathrm{Et}_{4} \mathrm{~N}\right]^{2-}(\mathrm{m} / \mathrm{z}: 248.960, z=2$, for $3 ; \mathrm{m} / z$ : 249.957, $z=2$, for $3{ }^{15} \mathrm{NO}$ ) as the prominent peak (Fig. S15S18†े).

To confirm that $\mathrm{NO}(\mathrm{g})$ is released from 2 (forming 3 among other products), solutions of 2 were mixed with the $\mathrm{NO}(\mathrm{g})$ trap $[\mathrm{Co}(\mathrm{T}(-\mathrm{OMe}) \mathrm{PP})](\mathrm{T}(-\mathrm{OMe}) \mathrm{PP}=5,10,15,20$-tetrakis(4-methoxyphenyl)-21H,23H-porphine). ${ }^{63}$ For example, mixing 2 and the $\mathrm{Co}^{\mathrm{II}}-\mathrm{P}(1: 2)$ in $\mathrm{CH}_{2} \mathrm{Cl}_{2}$ at $\mathrm{RT}$ for $24 \mathrm{~h}$ resulted in the $\{\mathrm{CoNO}\}^{8}$ complex $[\mathrm{Co}(\mathrm{T}(-\mathrm{OMe}) \mathrm{PP})(\mathrm{NO})]$ in $\sim 70 \%$ avg. yield as quantified by ${ }^{1} \mathrm{H}$ NMR $\left(\mathrm{CD}_{2} \mathrm{Cl}_{2}\right)$ and further verified by IR spectroscopy using $2-{ }^{15} \mathrm{NO}$ (Fig. S21-S23†). Notably, the reaction mixture becomes red over the course of the reaction. Workup of this solution after separating the Co-P compounds ( $\mathrm{MeOH}-$ insoluble) reveals the presence of 3 (MeOH-soluble) via ${ }^{1} \mathrm{H}$ NMR to confirm the fate of the $\{\mathrm{NiNO}\}^{10}$ complex 2. To eliminate bimolecular NO-transfer via a putative $\mathrm{Co} \cdots \mathrm{NO} \cdots \mathrm{Ni}$ intermediate, $\mathrm{NO}(\mathrm{g})$ release was further verified by vial-to-vial trapping reactions wherein a $\mathrm{CH}_{2} \mathrm{Cl}_{2}$ solution of the $\mathrm{Co}^{\mathrm{II}}-\mathrm{P}$ was separated from an MeCN solution of $2\left(\mathrm{CO}^{\mathrm{II}}-\mathrm{P}\right.$ in excess, see the ESI $\dagger$ ). Carrying out this reaction confirmed that $\mathrm{NO}(\mathrm{g})$ is indeed released from 2 (or $2{ }^{-15} \mathrm{NO}$ ) to generate the $\{\mathrm{CoNO}\}^{8}$ porphyrin complex (80\% avg. yield) as shown by ${ }^{1} \mathrm{H}$ NMR and IR measurements (Fig. S24†). In contrast, no reaction takes place between THF solutions of 2 with [Fe(TPP)Cl] $(1: 2$; TPP $=$ $5,10,15,20$-tetraphenylporphyrin), a common $\mathrm{HNO}$ (or $\mathrm{NO}^{-}$) trap. ${ }^{64}$ Although $\{\mathrm{NiNO}\}^{10}$ has not been characterized as 
a particularly labile EF notation, we note that the majority of these complexes are cationic or neutral without coordinated thiolate ligands. ${ }^{28}$ Indeed, the thiolate-ligated $\{\mathrm{NiNO}\}^{10}$ complex III photochemically releases NO to [Co(TPP)] in MeCN suggesting some lability in the Ni-NO bond. Furthermore, the RNNO bond is quite stable (as noted by formation of 3 ) and the energetically stabilized MOs that contribute to the electronic structure of 2 and 3 where HOMO-3 represents a bonding MO with primary contributions from $\sigma$-NR and $\sigma$-NO orbitals (Fig. S25†).

Density functional theory (DFT) computations have provided a deeper understanding of the electronic structure of a variety of metal nitrosyls, ${ }^{65,66}$ and we have employed them here for $\mathbf{2}$ and $\mathbf{3}$ at the OLYP/def2-TZVPP level of theory. Pure functionals such as BP86 and OLYP were used for geometry optimization and single point energy calculations, respectively, as these functionals have been established to deliver better matches with experimental geometries in MNO systems. ${ }^{67-69}$ Geometry optimization of 2 was performed with coordinates from the crystal structure to yield DFT-optimized complex $2 *$ (Fig. 4, Tables 1, S5 and S7 in the ESI $\dagger$ ). Structurally, $2 *$ replicates the metrics of 2 well, suggesting the computational model is reasonable. While the distances in $2 *$ are within $\pm 0.025 \AA$ of experimental values, the bond angles (especially $\mathrm{S}-\mathrm{Ni}-\mathrm{S}:-6.6^{\circ}$, and $\mathrm{Ni}-\mathrm{N}-\mathrm{O}:+3.6^{\circ}$ from 2) are slightly beyond the allowable tolerances for satisfactory DFT performance in small molecules (i.e., distances $\pm 0.03 \AA$; angles $\left.\pm 1^{\circ}\right) .{ }^{70}$ However, these rules may be broken to some degree because of the enhanced complexity arising from the covalent MNO unit in 2. The computations also reasonably match the two closely spaced $\mathrm{N}-\mathrm{O}$ stretching frequencies for the symmetric and asymmetric $\nu_{\mathrm{NO}}$ in the IR at 1730 and $1708 \mathrm{~cm}^{-1}$, respectively. The $\sim 30 \mathrm{~cm}^{-1}$ downshift from 2 is likely due to a slight overestimation of Ni-NO bond covalency arising from $\mathrm{Ni}-\mathrm{d} \pi$ backbonding. Previous calculations on three- ${ }^{71}$ and fourcoordinate $^{43,72}\{\mathrm{NiNO}\}^{10}$ complexes support a Ni ${ }^{\mathrm{II}}-{ }^{3} \mathrm{NO}^{-}\left(S_{\text {tot }}=\right.$ 0 , antiferromagnetically coupled) oxidation state assignment. This is comparable to high-spin nonheme $\{\mathrm{FeNO}\}^{7}$ systems that are classified as Fe ${ }^{\mathrm{III}}{ }^{3} \mathrm{NO}^{-}\left(S_{\text {tot }}=3 / 2\right) .{ }^{6,66,73}$ In the Fe case, ${ }^{3} \mathrm{NO}^{-}$ serves as a strong $\pi$-donor to afford a highly covalent $\mathrm{Fe}-\mathrm{NO}$ bond. ${ }^{74}$ The strength of this interaction originates from the effective nuclear charge on the metal, which is controlled by the
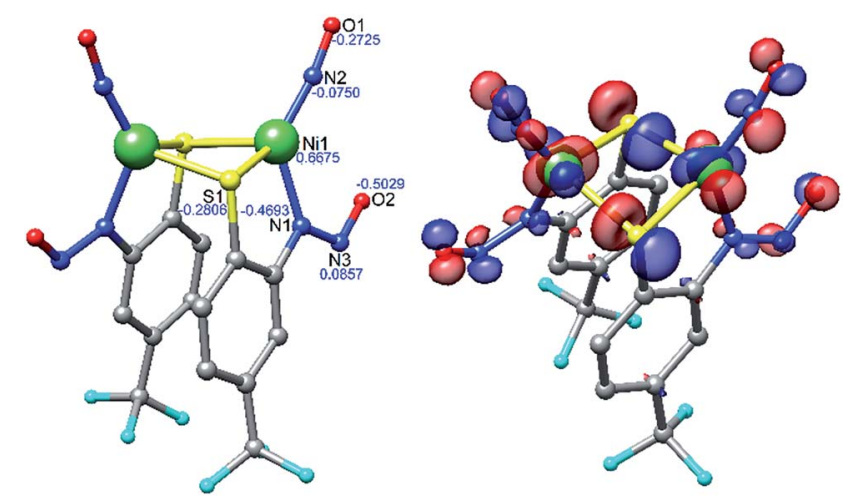

Fig. 4 DFT (OLYP/def2-TZVPP) optimized structure of $2 *$ (left) with natural population analysis charges in blue and $\mathrm{HOMO}$ (right). basicity of the supporting ligands. ${ }^{75}$ Thus, electron rich supporting ligands attenuate the $\pi$-basicity of ${ }^{3} \mathrm{NO}^{-}$to result in diminished $\mathrm{M}-\mathrm{NO}$ bond covalency. This property has been established in the $\{\mathrm{FeNO}\}^{7}$ case, but not yet for $\{\mathrm{NiNO}\}^{10}$. Indeed, examination of the frontier MOs of $2 *$ show that, much like other $\left\{\mathrm{NiNO}^{10}\right.$ systems with Tp ligands ${ }^{43,72}(\mathrm{Tp}=$ tris(pyrazolyl)borate), the LUMO is a $\pi^{*}$ MO primarily comprised of antibonding interactions between $\mathrm{Ni}-\mathrm{d} \pi$ and $\mathrm{NO}-\pi^{*}$ orbitals (Fig. S25 $\dagger$ ). On the other hand, the HOMO (Fig. 4) and HOMO-1 have little contribution from NO, but large contributions from Ni-d $\sigma(38.0 \%)$ and S-p $\sigma$ (19.3\%) orbitals of the $\mathrm{Ni}(\mu-\mathrm{SR})_{2} \mathrm{Ni}$ core. The HOMO is antibonding in nature and suggests a thermally unstable structure. As expected from analogous $\{\mathrm{FeNO}\}^{7}$ systems, based on the increased donor strength of the anionic nitrosamine-N/thiolate-S supporting ligands in $2^{*}$, the covalency in the $\mathrm{Ni}-\mathrm{N}-\mathrm{O}$ unit is less than in TpNi-NO complexes and rationalizes the observed lability of the $\mathrm{Ni}-\mathrm{NO}$ bond and the $\mathrm{Ni}(\mu-\mathrm{SR})_{2} \mathrm{Ni}$ core in 2 .

DFT computations on $3^{*}$ were performed in the same fashion as for $2^{*}$. Geometry optimized $3 *$ is square-planar $\left(\tau_{4}=\right.$ 0.09 ) with metric parameters on-par with the X-ray structure of 3 and within the error of the DFT method (Table S9†). Unlike 2*, the $\pi^{*}$ HOMO of $3^{*}$ is comprised primarily of $\mathrm{Ni}(\mathrm{d} \pi) / \mathrm{S}(\mathrm{p} \pi)$ contributions (Fig. S26 ${ }^{\dagger}$ ), typical of planar $\mathrm{Ni}^{\mathrm{II}}-\mathrm{N}_{2} \mathrm{~S}_{2}$ complexes with strong-field ligands and suggests a highly covalent Ni-SR bond. ${ }^{15}$

The formation of 2 likely follows a mechanistic path analogous to those observed in the reductive nitrosylation of $\mathrm{Cu}-$ amine systems, where one-equiv. of $\mathrm{NO}$ reacts with $\mathrm{Cu}{ }^{\mathrm{II}}-\mathrm{NR}_{2}$ complexes to yield $\mathrm{R}_{2} \mathrm{~N}-\mathrm{NO}$ and deligated $\mathrm{Cu}^{\mathrm{I}}{ }^{76,77}$ The difference here is that the nitrosated ligand remains coordinated and the resulting paramagnetic $\mathrm{Ni}$ binds NO radical. Our working model is depicted in Scheme 2. Complex

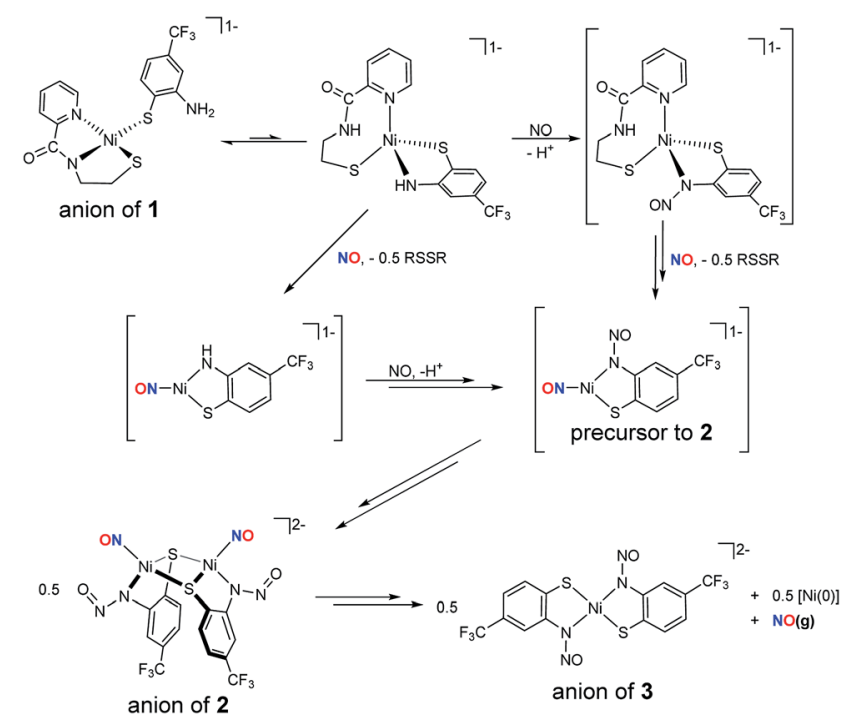

Scheme 2 Working model for the formation of $\{\mathrm{NiNO}\}^{10}$ complex 2 and $\mathrm{Ni}^{\mathrm{I}}-\mathrm{N}_{2} \mathrm{~S}_{2}$ complex 3 starting from $\mathrm{Ni}^{\mathrm{I}}-\mathrm{N}_{2} \mathrm{~S}_{2}$ monomer 1 . RSSR: disulfide of $\mathrm{nmp}^{2-}$, i.e., $\mathrm{N}$-(2-mercaptoethyl)picolinamide. Intermediates represented in brackets have not been spectroscopically identified. The py-N of RSSR is a possible $\mathrm{H}^{+}$receptor. 
$\mathbf{1}$ is likely in resonance with a distorted tetrahedral species which places the anilido- $\mathrm{N}$ in the coordination sphere. This proposal is supported by the presence of low intensity peaks in the ${ }^{1} \mathrm{H}$ NMR spectrum of $\mathbf{1}$ and may explain the difficulty in crystallizing this complex. ${ }^{16}$ On the other hand, X-ray absorption spectroscopic (XAS) characterization of 1 , not reported previously, suggests a four-coordinate planar $\mathrm{Ni}^{\mathrm{II}}$ center (XANES analysis, see Fig. S3†) with two $\mathrm{O} / \mathrm{N}$ - and S-ligands at $1.90 \AA$ and $2.17 \AA$ (EXAFS, Fig. S3, Table S4 $\dagger$ ), respectively. Thus, 1 is structurally analogous to other $[\mathrm{Ni}(\mathrm{nmp})(\mathrm{SR})]^{-}$complexes at least in the solid-state. Introduction of $\mathrm{NO}(\mathrm{g})$ can then result in either: (i) reduction of $\mathrm{Ni}^{\mathrm{II}}$ to $\mathrm{Ni}^{\mathrm{I}}$ and formation of $\mathrm{NO}^{+}$that nitrosates the coordinated amine, or (ii) nitrosylation of $\mathrm{Ni}$ to yield $\{\mathrm{NiNO}\}^{10}$ with the electron originating from the coordinated thiolate of $\mathrm{nmp}^{2-}$ to result in the disulfide. Our results do not differentiate either of these transformations, but the disulfide of $\mathrm{nmp}^{2-}$ (i.e., $\mathrm{nmpS}_{2}{ }^{1} \mathrm{H} \mathrm{NMR}$ and IR of the reaction mixture, see Fig. S19 and S20 $\dagger$ ) is spectroscopically observed in the reaction mixture and checked against independently synthesized $n m p S_{2}$. Thus, the fate of one proton and one electron is reasonably confirmed. At this point these intermediates can react with another equiv. of NO to yield the three-coordinate precursor to $\mathbf{2}$. Compound $\mathbf{3}$ forms through either disproportionation (shown in Scheme 2) to yield $\mathrm{a} \mathrm{Ni}^{0}$ species or ligand rearrangement via the loss of a $\mathrm{Ni}^{\mathrm{I}}-\mathrm{NO}$ fragment (not shown). In ligand rearrangement, the products would be a $\mathrm{Ni}^{\mathrm{I}}-\mathrm{N}_{2} \mathrm{~S}_{2}$ precursor to 3 (3-PC), an $\mathrm{L}-\mathrm{Ni}^{\mathrm{I}}-\mathrm{NO}$ species ( $\mathrm{L}=$ solvent), and free NO. Ultimately this $\mathrm{Ni}^{\mathrm{I}}$ intermediate oxidizes 3-PC to generate $\mathrm{Ni}^{\mathrm{II}}$ complex 3 and an $\mathrm{L}-\mathrm{Ni}^{0}-\mathrm{NO}$ complex that would presumably release $\mathrm{NO}(\mathrm{g})$ as evidenced by the $\mathrm{NO}(\mathrm{g})$ trap experiments (vide supra). While the reaction mechanism for the conversion of 2-to-3 is likely more complex, similar chemistry has been proposed for N-heterocyclic carbene (NHC) Ni-nitrosyls. $^{28,78}$ The details of this mechanism are still under investigation.

\section{Conclusions}

In conclusion, NiSOD model complex 1 reacts with $\mathrm{NO}(\mathrm{g})$ in the $\mathrm{Ni}^{\mathrm{II}}$ state to form the metastable $\{\mathrm{NiNO}\}^{10}$ dimeric complex 2 via loss of the $\mathrm{nmp}^{2-}$ ligand as the disulfide and $\mathrm{N}$-nitrosation of the $o$-aminobenzenethiolate ligand. Reaction of NO with $\mathbf{1}^{\mathbf{o x}}$, or $\mathrm{NO}^{+}$with 1 , only yields the $S, S$-bridged tetrameric compound $\left[\mathrm{Ni}_{4}(\mathrm{nmp})_{4}\right]$ through oxidation of the aromatic thiolate ligand. While any reaction with NO $(S=1 / 2)$ is generally unexpected for square-planar $(S=0) \mathrm{Ni}^{\mathrm{II}}$ complexes, this Ni-nitrosyl likely forms due to an equilibrium mixture of $\mathbf{1}$ and a tetrahedral $(S=$ 1) or five-coordinate derivative (Scheme 2). Even if NO were to result in an nmp-bound $\mathrm{Ni}-\mathrm{NO}$ complex, the resulting $\{\mathrm{NiNO}\}^{9}$ (reaction of 1 with NO) or $\{\mathrm{NiNO}\}^{8}$ (reaction of $\mathbf{1}^{\mathbf{o x}}$ with NO) oxidation levels have yet to be defined and support an outersphere superoxide interaction in NiSOD. Although these EF notations have yet to be accessed, one would propose that NiSOD mimetics, especially with strong-field carboxamido-N and alkyl-thiolato-S donors, would surely stabilize such an electron poor species. Furthermore, the properties of complexes such as 2 extend to biology, where analogous S-bridged mononitrosyl species, i.e., Fe-S clusters and tetrahedral $(\mathrm{RS})_{3} \mathrm{Fe}-\mathrm{NO}$ complexes are proposed as intermediates in the repair of NO-damaged clusters. ${ }^{79-81}$ Complex 2 is stable in the solid-state but breaks down slowly in solution causing rupture of the $\mathrm{Ni}(\mu-\mathrm{SR})_{2} \mathrm{Ni}$ core and release of NO that was trapped in near quantitative yield with a $\mathrm{Co}^{\mathrm{II}}$-porphyrin receptor. The resulting $\mathrm{Ni}^{\mathrm{II}}-\mathrm{N}_{2} \mathrm{~S}_{2}$ complex 3 (coordination of two $o$-aminobenzenethiolate in trans configuration) was isolated and structurally/spectroscopically characterized as the ultimate $\mathrm{Ni}$ breakdown product with the nitrosamine unit still intact. This release may take place through a disproportionation mechanism (or through ligand rearrangement), as has been proposed in other Ni-nitrosyls, to a yet ill-defined $\mathrm{Ni}^{0}$ complex (see Scheme 2). ${ }^{28,78}$ Hence, thiolate-supported $\{\mathrm{NiNO}\}^{10}$ cores are reactive. While nitrosamines have been utilized as sources of $\mathrm{NO}$, the RN-NO homolytic bond dissociation energy (BDE) is high (87.7 kcal mol ${ }^{-1}$ (ref. 82)) compared to more traditional small molecule sources of NO such as nitrosothiols (RSNO) that have RS-NO BDEs between 20-32 $\mathrm{kcal} \mathrm{mol}^{-1} \cdot{ }^{\mathbf{8 3 , 8 4}}$ Overall, the electronic structures of $\{\mathrm{NiNO}\}^{10}$ complexes are modulated by the supporting ligands. Indeed, the majority are stable entities; however, a small number are reactive and result in release of NO (thiolate-supported/anionic complexes 2 and III) or generate other reactive intermediates of environmental significance such as hyponitrite $\left(\mathrm{N}_{2} \mathrm{O}_{2}{ }^{2-}\right)$ in five-coordinate $\{\mathrm{NiNO}\}^{10}$ species $^{85}$ (highly reduced NO, with a severely bent $\mathrm{Ni}-\mathrm{N}-\mathrm{O}$ angle $=130^{\circ}$ ).

\section{Conflicts of interest}

There are no conflicts to declare.

\section{Acknowledgements}

This work was supported by a grant from the National Science Foundation, Division of Chemistry, Chemistry of Life Sciences Program (CHE-1506375) to TCH. TLS and SPD were supported by the National Institutes of Health (NIH) DK068139 (T. L. S.), DK101230 (SPD). XAS studies were performed at the Stanford Synchrotron Radiation Lightsource (SSRL). SSRL is a national user facility operated by Stanford University on behalf of the Department of Energy (DOE), Office of Basic Energy Sciences. The SSRL Structural Molecular Biology Program is supported by the DOE, Office of Biological and Environmental Research, and by the NIH, National Center for Research Resources, Biomedical Technology Program. We thank Dr Dennis R. Phillips and Dr Chau-Wen Chou from the Proteomics and Mass Spectrometry (PAMS) Core Facility at UGA for their assistance with MS measurements. Instrumentation in the PAMS facility was purchased in part with funds from NIH Grant 1S10RR02885901. Funds for PAMS facility operations were provided by the UGA Office of the Vice President for Research (OVPR) and UGA Department of Chemistry. This study was supported in part by resources and technical expertise from the Georgia Advanced Computing Resource Center, a partnership between UGA's OVPR and Office of the Vice President for Information Technology. We also acknowledge Ms Yi Liu (UGA Department of 
Chemistry) for assistance with the $\mathrm{NO}(\mathrm{g})$ vial-to-vial trap experiments.

\section{Notes and references}

1 S. Moncada and E. A. Higgs, Br. J. Pharmacol., 2006, 147, S193-S201.

2 L. J. Ignarro, Nitric Oxide Biology and Pathobiology, Academic Press, San Diego, CA, 2000.

3 J. M. Fukuto, S. J. Carrington, D. J. Tantillo, J. G. Harrison, L. J. Ignarro, B. A. Freeman, A. Chen and D. A. Wink, Chem. Res. Toxicol., 2012, 25, 769-793.

4 C. L. Bianco, J. P. Toscano, M. D. Bartberger and J. M. Fukuto, Arch. Biochem. Biophys., 2017, 617, 129-136.

5 M. D. Clay, C. A. Cosper, F. E. Jenney, M. W. W. Adams and M. K. Johnson, Proc. Natl. Acad. Sci. U. S. A., 2003, 100, 37963801.

6 C. A. Brown, M. A. Pavlosky, T. E. Westre, Y. Zhang, B. Hedman, K. O. Hodgson and E. I. Solomon, J. Am. Chem. Soc., 1995, 117, 715-732.

7 M. J. Nelson, J. Biol. Chem., 1987, 262, 12137-12142.

8 V. J. Chen, A. M. Orville, M. R. Harpel, C. A. Frolik, K. K. Surerus, E. Münck and J. D. Lipscomb, J. Biol. Chem., 1989, 264, 21677-21681.

9 P. L. Roach, I. J. Clifton, C. M. H. Hensgens, N. Shibata, C. J. Schofield, J. Hajdu and J. E. Baldwin, Nature, 1997, 387, 827-830.

10 J. A. McCleverty, Chem. Rev., 2004, 104, 403-418.

11 E. M. Gale, A. K. Patra and T. C. Harrop, Inorg. Chem., 2009, 48, 5620-5622.

12 E. M. Gale, B. S. Narendrapurapu, A. C. Simmonett, H. F. Schaefer III and T. C. Harrop, Inorg. Chem., 2010, 49, 7080-7096.

13 E. M. Gale, D. M. Cowart, R. A. Scott and T. C. Harrop, Inorg. Chem., 2011, 50, 10460-10471.

14 E. M. Gale, A. C. Simmonett, J. Telser, H. F. Schaefer III and T. C. Harrop, Inorg. Chem., 2011, 50, 9216-9218.

15 E. P. Broering, P. T. Truong, E. M. Gale and T. C. Harrop, Biochemistry, 2013, 52, 4-18.

16 E. P. Broering, S. Dillon, E. M. Gale, R. A. Steiner, J. Telser, T. C. Brunold and T. C. Harrop, Inorg. Chem., 2015, 54, 3815-3828.

17 R. A. Steiner, S. P. Dzul, T. L. Stemmler and T. C. Harrop, Inorg. Chem., 2017, 56, 2849-2862.

18 P. T. Truong, E. M. Gale, S. P. Dzul, T. L. Stemmler and T. C. Harrop, Inorg. Chem., 2017, 56, 7761-7780.

19 D. P. Barondeau, C. J. Kassmann, C. K. Bruns, J. A. Tainer and E. D. Getzoff, Biochemistry, 2004, 43, 8038-8047.

20 A. T. Fiedler, P. A. Bryngelson, M. J. Maroney and T. C. Brunold, J. Am. Chem. Soc., 2005, 127, 5449-5462.

21 J. Shearer and N. Zhao, Inorg. Chem., 2006, 45, 9637-9639.

22 V. Mathrubootham, J. Thomas, R. Staples, J. McCraken, J. Shearer and E. L. Hegg, Inorg. Chem., 2010, 49, 5393-5406.

23 D. Nakane, Y. Wasada-Tsutsui, Y. Funahashi, T. Hatanaka, T. Ozawa and H. Masuda, Inorg. Chem., 2014, 53, 6512-6523. 24 J. Shearer, Acc. Chem. Res., 2014, 47, 2332-2341.
25 N. G. Connelly and W. E. Geiger, Chem. Rev., 1996, 96, 877910.

26 J. H. Enemark and R. D. Feltham, Coord. Chem. Rev., 1974, 13, 339-406. $\left\{\mathrm{MNO}^{n}, n=\right.$ total sum of electrons in the metal-d and NO- $\pi^{*}$ orbitals.

27 D. L. H. Williams, Acc. Chem. Res., 1999, 32, 869-876.

28 A. M. Wright and T. W. Hayton, Comments Inorg. Chem., 2012, 33, 207-248.

29 L. Yang, D. R. Powell and R. P. Houser, Dalton Trans., 2007, 955-964.

30 P. J. Schebler, C. G. Riordan, I. A. Guzei and A. L. Rheingold, Inorg. Chem., 1998, 37, 4754-4755.

31 W.-F. Liaw, C.-Y. Chiang, G.-H. Lee, S.-M. Peng, C.-H. Lai and M. Y. Darensbourg, Inorg. Chem., 2000, 39, 480-484.

32 L. S. Maffett, K. L. Gunter, K. A. Kreisel, G. P. A. Yap and D. Rabinovich, Polyhedron, 2007, 26, 4758-4764.

33 A. G. Tennyson, S. Dhar and S. J. Lippard, J. Am. Chem. Soc., 2008, 130, 15087-15098.

34 A. M. Wright, H. T. Zaman, G. Wu and T. W. Hayton, Inorg. Chem., 2013, 52, 3207-3216.

35 J. H. Enemark, Inorg. Chem., 1971, 10, 1952-1957.

36 J. Kriege-Simondsen, G. Elbaze, M. Dartiguenave, R. D. Feltham and Y. Dartiguenave, Inorg. Chem., 1982, 21, 230-236.

37 A. F. M. M. Rahman, G. Salem, F. S. Stephens and S. B. Wild, Inorg. Chem., 1990, 29, 5225-5230.

38 D. J. Darensbourg, T. J. Decuir, N. W. Stafford, J. B. Robertson, J. D. Draper, J. H. Reibenspies, A. Kathó and F. Joó, Inorg. Chem., 1997, 36, 4218-4226.

39 C. E. MacBeth, J. C. Thomas, T. A. Betley and J. C. Peters, Inorg. Chem., 2004, 43, 4645-4662.

40 V. M. Iluc, A. J. M. Miller and G. L. Hillhouse, Chem. Commun., 2005, 5091-5093.

41 V. K. Landry, K. Pang, S. M. Quan and G. Parkin, Dalton Trans., 2007, 820-824.

42 A. M. Wright, H. T. Zaman, G. Wu and T. W. Hayton, Inorg. Chem., 2014, 53, 3108-3116.

43 S. Soma, C. Van Stappen, M. Kiss, R. K. Szilagyi, N. Lehnert and K. Fujisawa, J. Biol. Inorg. Chem., 2016, 21, 757-775.

44 R. Huber, R. Langer and W. Hoppe, Acta Crystallogr., 1965, 18, 467-473.

45 L. K. Keefer, S. M. Wang, T. Anjo, J. C. Fanning and C. S. Day, J. Am. Chem. Soc., 1988, 110, 2800-2806.

46 J. Lee, L. Chen, A. H. West and G. B. Richter-Addo, Chem. Rev., 2002, 102, 1019-1066.

47 F. J. Lalor, T. J. Desmond, G. Ferguson and P. Y. Siew, J. Chem. Soc., Dalton Trans., 1982, 1981-1985.

48 F. Doctorovich and F. Di Salvo, Acc. Chem. Res., 2007, 40, 985-993.

49 G.-B. Yi, M. A. Khan and G. B. Richter-Addo, J. Am. Chem. Soc., 1995, 117, 7850-7851.

50 G. B. Richter-Addo, Acc. Chem. Res., 1999, 32, 529-536.

51 F. Di Salvo, D. A. Estrin, G. Leitus and F. Doctorovich, Organometallics, 2008, 27, 1985-1995.

52 K. S. Chong, S. J. Rettig, A. Storr and J. Trotter, Can. J. Chem., 1979, 57, 3099-3106. 
53 R. L. Williams, R. J. Pace and G. J. Jeacocke, Spectrochim. Acta, 1964, 20, 225-236.

54 J. Mason, L. F. Larkworthy and E. A. Moore, Chem. Rev., 2002, 102, 913-934.

55 M. H. Lim, B. A. Wong, W. H. Pitcock Jr, D. Mokshagundam, M.-H. Baik and S. J. Lippard, J. Am. Chem. Soc., 2006, 128, 14364-14373.

56 M. H. Lim, D. Xu and S. J. Lippard, Nat. Chem. Biol., 2006, 2, 375-380.

57 R. Bonnett, R. Holleyhead, B. L. Johnson and E. W. Randall, J. Chem. Soc., Perkin Trans. 1, 1975, 2261-2264.

58 T. C. Harrop and P. K. Mascharak, Coord. Chem. Rev., 2005, 249, 3007-3024.

59 T. Kawamoto, H. Kuma and Y. Kushi, Bull. Chem. Soc. Jpn., 1997, 70, 1599-1606.

60 T. Kawamoto and Y. Kushi, Inorg. Chim. Acta, 1998, 282, 7175.

61 S. Inoue, M. Mitsuhashi, T. Ono, Y.-N. Yan, Y. Kataoka, M. Handa and T. Kawamoto, Inorg. Chem., 2017, 56, 12129-12138.

62 D. Herebian, E. Bothe, E. Bill, T. Weyhermüller and K. Wieghardt, J. Am. Chem. Soc., 2001, 123, 10012-10023.

63 M. Kumar, N. A. Dixon, A. C. Merkle, M. Zeller, N. Lehnert and E. T. Papish, Inorg. Chem., 2012, 51, 7004-7006.

64 S. E. Bari, M. A. Martí, V. T. Amorebieta, D. A. Estrin and F. Doctorovich, J. Am. Chem. Soc., 2003, 125, 15272-15273.

65 A. Ghosh, Acc. Chem. Res., 2005, 38, 943-954.

66 T. C. Berto, A. L. Speelman, S. Zheng and N. Lehnert, Coord. Chem. Rev., 2013, 257, 244-259.

67 J. Conradie and A. Ghosh, J. Phys. Chem. B, 2007, 111, 1262112624.

68 K. H. Hopmann, L. Noodleman and A. Ghosh, Chem.-Eur. J., 2010, 16, 10397-10408.

69 L. E. Goodrich, F. Paulat, V. K. K. Praneeth and N. Lehnert, Inorg. Chem., 2010, 49, 6293-6316.
70 J.-F. Guillemoles, V. Barone, L. Joubert and C. Adamo, J. Phys. Chem. A, 2002, 106, 11354-11360.

71 J. Conradie and A. Ghosh, Inorg. Chem., 2014, 53, 4847-4855.

72 N. C. Tomson, M. R. Crimmin, T. Petrenko, L. E. Rosebrugh, S. Sproules, W. C. Boyd, R. G. Bergman, S. DeBeer, F. D. Toste and K. Wieghardt, J. Am. Chem. Soc., 2011, 133, 18785-18801.

73 J. Conradie, D. A. Quarless, H.-F. Hsu, T. C. Harrop, S. J. Lippard, S. A. Koch and A. Ghosh, J. Am. Chem. Soc., 2007, 129, 10446-10456.

74 A. L. Speelman and N. Lehnert, Angew. Chem., Int. Ed., 2013, 52, 12283-12287.

75 T. C. Berto, M. B. Hoffman, Y. Murata, K. B. Landenberger, E. E. Alp, J. Zhao and N. Lehnert, J. Am. Chem. Soc., 2011, 133, 16714-16717.

76 P. C. Ford, B. O. Fernandez and M. D. Lim, Chem. Rev., 2005, 105, 2439-2456.

77 K. Tsuge, F. DeRosa, M. D. Lim and P. C. Ford, J. Am. Chem. Soc., 2004, 126, 6564-6565.

78 M. S. Varonka and T. H. Warren, Organometallics, 2010, 29, 717-720.

79 C. T. Tran, P. G. Williard and E. Kim, J. Am. Chem. Soc., 2014, 136, 11874-11877.

80 J. Fitzpatrick and E. Kim, Acc. Chem. Res., 2015, 48, 24532461.

81 J. Fitzpatrick and E. Kim, Inorg. Chem., 2015, 54, 1055910567.

82 X.-Q. Zhu, J.-Q. He, Q. Li, M. Xian, J. Lu and J.-P. Cheng, J. Org. Chem., 2000, 65, 6729-6735.

83 M. D. Bartberger, J. D. Mannion, S. C. Powell, J. S. Stamler, K. N. Houk and E. J. Toone, J. Am. Chem. Soc., 2001, 123, 8868-8869.

84 J.-M. Lü, J. M. Wittbrodt, K. Wang, Z. Wen, H. B. Schlegel, P. G. Wang and J.-P. Cheng, J. Am. Chem. Soc., 2001, 123, 2903-2904.

85 A. M. Wright, G. Wu and T. W. Hayton, J. Am. Chem. Soc., 2012, 134, 9930-9933. 